() Москалюк В.Д., Соколенко М.О., Сорохан В.Д., 2015

УДК 616.98:578.825.11-06:616.98-097:578.828.6

\author{
В.Д. Москалюк, М.О. Соколенко, В.Д. Сорохан
}

\title{
ІМУННИЙ СТАТУС ХВОРИХ З ГЕРПЕТИЧНОЮ ІНФЕКЦІЕЮ НА ФОНІ ВІЛ-ІНФЕКЦІї/СНІДУ
}

\author{
Буковинський державний медичний університет
}

\begin{abstract}
Обстеження 37 хворих на ВІЛ-інфекцію у поєднанні з герпетичною інфекцією (лабіальний герпес та/або афртозний стоматит, генітальний, оперізувальний герпес та інфрекційний мононуклеоз, окремо чи в комбінації) показало, що у разі такого поєднання вміст лімфооцитів при III і IV клінічній стадії імунодефріциту був достовірно нижчим, ніж при герпетичній моноінфекції. Таким же достовірним було зниження рівня CD4 при II-IV стадії ВІЛ-інфрекції у комбінації з герпетичною інфрекцією і відносне збільшення кількості T-супресорів порівняно з герпетичною моноінфекцією. За наявності вірусу герпесу в організмі ВІЛ-інфрікованих дещо меншою мірою знижується імунорегуляторний показник, що свідчить про певний конкуруючий вплив вірусу герпесу на регуляторні субпопулячії.

У хворих на ВІЛ- і герпетичну коінорекцію співвідношення сироваткових концентрацій ІЛ-8, ІЛ-10, ІЛ-12 та ІЛ-17 зазнає максимального дисбалансу. Причому значно зростає вміст не тільки прозапальних (ІЛ-8, ІЛ-17), але й протизапального цитокіну ІЛ-10. Водночас значно знижується рівень прозапального ІЛ-12 у хворих з тяжким ступенем імуносупресії. Паралельно суттєво зростає сироватковий рівень протизапального цитокіну ІЛ-10 на всіх стадіях комбінованої ВІЛ- та герпесвірусної інфекції, незалежно від клінічної стадії недуги.
\end{abstract}

При поєднанні ВІЛ- і герпетичної інсрекції виявили сильну зворотну кореляцію між рівнем ІЛ-8 і кількістю CD4-лімфоцитів ( $r=-0,72, p<0,05)$, сильну зворотну кореляцію $(r=-0,79, p<0,05)$ між значенням ІЛ-10 і кількістю CD4-лімороцитів, зворотну кореляцію середньої сили $(r=-0,35, p<0,05)$ між вмістом ІЛ-17 і кількістю CD4лімфоцитів, а також слабку пряму $(r=0,08, p<0,05)$ - між значеннями ІЛ-12 та кількістю CD4-лімфоцитів.

У хворих з таким поєднанням вірусних інфекцій ще й суттєво зростає рівень циркулюючих імунних комплексів при практично незмінному титрі імуноглобулінів A, M i G.

Ключові слова: ВІЛ-інфрекція, герпетична інфрекція, клітинний та гуморальний імунітет, цитокіновий cmamyc.
Як відомо, герпетична інфекція належить до СНІДіндикаторних захворювань і може завершуватись летально у хворих на ВІЛ-інфекцію. На тлі набутого імунодефріциту герпетична інфрекція характеризується як опортуністична ко-інфекція. Крім того, зазначене захворювання спричиняє прогресування ВІЛ-інфекції. 3 наростанням ступеня імунодефріциту, який корелює зі зниженням рівня CD4+-лімфроцитів, зростають ризики активації герпетичної інфекції, розвиваються генералізовані її фрорми з ураженням внутрішніх органів, очей, нервової системи $[1,2]$.

Активація герпесвірусних інфрекцій у ВІЛ-інфікованих хворих, крім загального посилення реплікації ВІЛ, відбувається з підвищеним виділенням віріонів ВІЛ у місцях герпетичних шкірних висипань, які не завжди мають характерний для герпесу вигляд. Найбільш важливо те, що при цьому можуть утворюватися частки змішаного фенотипу - віріони ВІЛ, «одягнені» в оболонку герпесу. Такі «закамуфрльвані» частки, на відміну від звичайних віріонів ВІЛ, здатні інфрікувати різні типи клітин, Включаючи епітеліоцити і фрібробласти, даючи при цьому продуктивну ВІЛ-інфекцію, тобто стає можливим зараження ВІЛ через контакти з шкірою і слизовою оболонкою [3-5].

При герпесі розвиваються імунодесріцитні стани, обумовлені недостатністю різних ланок імунної системи та її нездатністю елімінувати вірус з організму. Зберігаючись протягом усього життя, іноді в досить високих титрах, віруснейтралізуючі антитіла, хоча і перешкоджають розповсюдженню, але не запобігають виникненню рецидивів.

Мета роботи - виявити патогенетичну та прогностичну значущість показників імунного та цитокінового статусу у хворих на герпетичну і ВІЛ-інсрекцію.

\section{Пацієнти і методи}

Обстежили 131 хворого на ВІЛ-інфекцію, герпетичну інфрекцію, окремо та у поєднанні. Серед зазначених пацієнтів було 70 (53,4 \%) чоловіків і 61 (46,6 \%) жінка віком від 19 до 49 років, середній вік становив $(31,4 \pm 0,9)$ року. Усіх хворих поділили на три групи. До першої увійшли 59 хворих на різні клінічні форми герпетичної інфекції: 11 - на лабіаль- 


\section{ОРИГІНАЛЬНІ ДОСЛІДЖЕННЯ}

ний герпес та/або афртозний стоматит, 10 - на генітальний герпес, 21 - на оперізувальний герпес і 17 - на інфекційний мононуклеоз. До другої - 35 хворих на ВІЛ-інфекцію, серед яких було 7 (20,0 \%) пацієнтів у I клінічній стадії, 15 (42,9 \%) - у II, 7 (20,0 \%) - у III, 6 (17,1 \%) - у IV клінічній стадії. До третьої групи було включено 37 осіб, в яких герпетична інсрекція поєднувалася з ВІЛ-інфекцією. Серед зазначених представників третьої групи було 7 (18,9 \%) хворих у I клінічній стадії, 16 (43,2 \%) - у II, 8 (21,6 \%) - у III, 6 (16,2 \%) - у IV клінічній стадії.

Діагноз ВІЛ-інсрекції був встановлений на підставі епідеміологічного анамнезу, клінічних даних і підтверджений виявленням специфрічних антитіл до ВІЛ у реакції імуноферментного аналізу (ІФА) і в реакції імунного блотингу.

При встановленні діагнозу брали до уваги клінікоепідеміологічні дані та результати лабораторних методів дослідження: серологічного та імунологічного (у т. ч. визначення вмісту CD4 ${ }^{+}$-лімфоцитів). Рівень CD4 ${ }^{+}-$ лімфоцитів досліджували після зникнення симптомів супутнього гострого інфекційного захворювання (не менше як через 4 тижні). Розширений спектр імунологічних показників у хворих на ВІЛ-інфрекцію був вивчений методом проточної цитометрії.

Контрольну групу склали 30 практично здорових людей, цілком зіставних за віковою категорією та статевим складом.

Статистичну обробку отриманих результатів проводили за допомогою програмного комплексу STATISTICA 6.0 з використанням методу варіаційної статистики з визначенням достовірності за допомогою непараметричного методу Вілкоксона для незалежних сукупностей. Для порівняння двох незалежних груп використовували U критерій МаннаУїтні. Розбіжності вважали статистично значущими при $\mathrm{p}<0,05[6]$.

\section{Результати досліджень та їх обговорення}

Враховуючи суттєвіший вплив на імунологічні показники клінічної стадії ВІЛ-інфекції, ніж клінічної фрорми герпетичної інфрекції, ми порівняли зазначені показники у хворих на герпесвірусну та ВІЛ-інфекцію-мікст 3 відповідними значеннями пацієнтів 3 маніфрестацією герпетичної інфекції, а також ВІЛ-інфікованих (табл. 1). При цьому у хворих на герпетичну інсрекцію використовували середнє значення конкретного досліджуваного імунологічного показника, незалежно від маніфрестації її клінічної форми.

Кількість лімфроцитів у хворих на ВІЛ-інфекцію порівняно $з$ пацієнтами з маніфестацією герпетичної інфекції знижувалась, однак статистично достовірною ця різниця була тільки при III і IV клінічних стадіях - $(0,83 \pm 0,48)$ і $(0,47 \pm 0,31)$ відповідно проти $(2,80 \pm 0,79)$ Г/л ( $<<0,05$, табл. 1).

Рівень CD4-лімсоцитів закономірно характеризувався такою ж динамікою, хоча статистично вагомою різниця була тільки при II, III і IV клінічній стадії ВІЛ-інфекції $(419,3 \pm 54,1),(317,7 \pm 52,6)$ і $(117,9 \pm 82,4)$ відповідно проти $(972,2 \pm 74,8)$ клітин/мкл $(p<0,05-0,02)$.

А от вміст субпопуляції лімфроцитів CD8, які представлені переважно цитотоксичними клітинами, знижений тільки в групі хворих з герпетичною інсеекцією порівняно з ВІЛ-інфрікованими. Щоправда, достовірною ця різниця була тільки при II і III клінічній стадії ВІЛінсрекції - $(730,3 \pm 52,4)$ і $(829,0 \pm 85,6)$ відповідно проти $(457,7 \pm 53,4)$ клітин/мкл у хворих на герпесвірусну інфекцію ( $<0,05$, мал. 1). Відомо, що френотипи цих клітин не $є$ мішенню для вірусу імунодефіциту людини і збільшення їх кількості при ВІЛ-інфекції пов'язане не із залученням до патологічного процесу, а з нижчим вмістом інших фенотипів клітин, тобто підвищення рівня CD8-лімфроцитів можна розцінювати як відносне.

Кількість CD16-клітин, що виконують переважно кілерну функцію (їх прийнято вважати натуральними кілерами), достовірно не відрізняється у всіх порівнюваних групах (p>0,05). За даними літератури відомо [7], що натуральним кілерам в основному відводиться роль в протипухлинному захисті. При вірусних інфекціях, зокрема при герпетичній, ця субпопуляція клітин має певне значення на початковому етапі розвитку захворювання. Можливо, тому в спостережуваних групах пацієнтів вміст CD16-клітин істотно не відрізняється.

Особливу діагностичну і прогностичну значущість при інсрекціях, пов'язаних 3 вірусом імунодефіциту людини, має імунорегуляторний індекс CD4/CD8. Цей показник значно знижується в групі ВІЛ-інфрікованих у вигляді моноінсрекції, причому при II, III і IV клінічній стадії недуги він достовірно відрізняється від значення у пацієнтів з клінічною маніфестацією герпетичної інфрекції - $(0,57 \pm 0,15),(0,38 \pm 0,20)$ і $(0,20 \pm 0,11)$ проти $(2,12 \pm 0,28)$ $(p<0,05-0,02)$.

У хворих на мікст-інфекцію вірусами герпесу й ВІЛ та ВІЛ-моноінфекцію аналіз імунологічних даних достовірних змін жодного з досліджуваних показників не виявив.

При поєднаному перебігу герпетичної і ВІЛ-інфекції спостерігали таку ж динаміку аналізованих показників, що й при ВІЛ-моноінфекції. Так, вміст лімфоцитів у хворих на мікст-інфекцію при III і IV клінічній стадії імунодефріциту був достовірно нижчим, ніж при герпетичній інфекції - $(0,73 \pm 0,33)$ і $(0,65 \pm 0,30)$ проти $(2,80 \pm 0,79)$ Г/л $(p<0,05)$.

Таким же достовірним було зниження рівня CD4 при II-IV стадії ВІЛ-інфрекції у комбінації з герпетичною інфекцією $(p<0,05-0,02)$ і відносне збільшення кількості Т-супресорів $(p<0,05)$ порівняно 3 герпетичною моноінфекцією. 


\section{ОРИГІНАЛЬНІ ДОСЛІДЖЕННЯ}

Таблиця 1

Показники клітинного, гуморального імунітету та цитокінового статусу у хворих на герпетичну

і ВІЛ-інфекцію окремо і в поєднанні $(\mathrm{M} \pm \mathrm{m})$

\begin{tabular}{|c|c|c|c|c|c|c|c|}
\hline \multirow{3}{*}{ Показник } & \multirow{3}{*}{$\begin{array}{c}\text { Герпесвірусна } \\
\text { інфрекція } \\
(\mathrm{n}=59) \\
\end{array}$} & \multirow{2}{*}{\multicolumn{5}{|c|}{$\frac{\text { Поєднання герпетичної і ВІЛ-інфекції (n=37) }}{\text { клінічна стадія ВІЛ-інсекції }}$}} & \multirow{3}{*}{$\begin{array}{c}\text { Здорові особи } \\
(n=30)\end{array}$} \\
\hline & & \multicolumn{4}{|c|}{ клінічна стадія ВІЛ-інфрекції } & & \\
\hline & & $I(n=7)$ & II $(n=16)$ & \multicolumn{2}{|l|}{ III $(n=8)$} & IV $(n=6)$ & \\
\hline Лейкоцити, Г/л & $5,43 \pm 0,81$ & $5,51 \pm 1,48$ & $5,30 \pm 0,83$ & \multicolumn{2}{|l|}{$5,05 \pm 1,93$} & $4,43 \pm 1,88$ & $6,73 \pm 0,62$ \\
\hline Лімфоцити, Г/л & $2,80 \pm 0,79$ & $1,62 \pm 0,92$ & $1,20 \pm 0,55$ & \multicolumn{2}{|c|}{$0,73 \pm 0,33^{*}, * *$} & $0,65 \pm 0,30^{*}$, ** & $2,68 \pm 0,45$ \\
\hline CD3, клітин/мкл & $1096,5 \pm 188,9$ & $1644,8 \pm 641,2$ & $1153,6 \pm 224,3$ & \multicolumn{2}{|c|}{$992,7 \pm 327,0$} & $995,5 \pm 229,4$ & $1993,6 \pm 188,9$ \\
\hline CD4, клітин/мкЛ & $972,2 \pm 74,8$ & $1122,9 \pm 181,4$ & $531,7 \pm 66,1^{*}, * *$ & \multicolumn{2}{|c|}{$351,2 \pm 69,9^{*}$,** } & $134,8 \pm 79,4^{*, ~ * \star ~}$ & $1422,5 \pm 95,7$ \\
\hline CD8, клітин/мкл & $457,7 \pm 53,4$ & $525,8 \pm 83,0$ & $788,1 \pm 76,7^{*}, * *$ & \multicolumn{2}{|c|}{$730,3 \pm 88,6^{*}, * *$} & $598,4 \pm 95,3$ & $537,8 \pm 60,2$ \\
\hline CD16, клітин/мкл & $285,8 \pm 49,1$ & $322,4 \pm 76,9$ & $303,5 \pm 49,1$ & \multicolumn{2}{|c|}{$244,8 \pm 56,6$} & $263,2 \pm 67,2$ & $354,3 \pm 51,0$ \\
\hline CD4/CD8 (IPI) & $2,12 \pm 0,28$ & $2,21 \pm 0,63$ & $0,65 \pm 0,32^{*}$, ** & \multicolumn{2}{|c|}{$0,46 \pm 0,22^{*}, * *$} & $0,26 \pm 0,13^{*},{ }^{* *}$ & $2,65 \pm 0,27$ \\
\hline ІЛ-8, пг/мЛ & $22,23 \pm 7,53$ & $65,34 \pm 17,08^{\star \star * *}$ & $89,65 \pm 22,43^{*, * *}$ & $130,54 \pm 46,1$ & $9^{*, * *}$ & $227,06 \pm 53,97^{*, *}$ & $14,38 \pm 5,66$ \\
\hline ІЛ-10, пг/мЛ & $0,185 \pm 0,074$ & $2,248 \pm 0,576^{* \text {,** }}$ & $2,958 \pm 0,463^{*, * *}$ & $5,384 \pm 1,06$ & & $6,493 \pm 1,210^{*}$, ** & $0,118 \pm 0,033$ \\
\hline ІЛ-12, пг/мЛ & $5,48 \pm 1,61$ & $5,12 \pm 2,47$ & $4,25 \pm 0,75$ & $3,09 \pm 1,7$ & & $1,22 \pm 0,70^{\star},{ }^{\star *}$ & $7,85 \pm 2,13$ \\
\hline ІЛ-17, пг/мЛ & $0,652 \pm 0,237$ & $0,749 \pm 0,458$ & $0,884 \pm 0,362$ & $1,206 \pm 0,50$ & & $2,850 \pm 0,761^{*},{ }^{* *}$ & $0,534 \pm 0,141$ \\
\hline $\lg \mathrm{A}$, г/л & $2,62 \pm 0,63$ & $1,61 \pm 0,39$ & $1,79 \pm 0,26$ & $1,89 \pm 0,51$ & & $1,72 \pm 0,49$ & $1,39 \pm 0,26$ \\
\hline $\operatorname{lgM}$, г/л & $1,64 \pm 0,39$ & $1,76 \pm 0,64$ & $1,53 \pm 0,36$ & $1,79 \pm 0,46$ & & $1,14 \pm 0,60$ & $1,88 \pm 0,31$ \\
\hline $\operatorname{lgG}$, г/л & $7,47 \pm 1,92$ & $6,36 \pm 1,40$ & $6,20 \pm 0,94$ & $6,65 \pm 1,76$ & & $5,83 \pm 1,42$ & $6,54 \pm 1,60$ \\
\hline ЦІК, опт. од. & $58,6 \pm 10,1$ & $69,4 \pm 12,7$ & $144,9 \pm 24,3^{*}$, ** & $168,0 \pm 55,2$ & & $199,6 \pm 64,0^{*}$, ** & $52,7 \pm 8,5$ \\
\hline & & & ворі на ВІЛ-інфек & цію $(n=35)$ & & & \\
\hline Показник & & & клінічна ста & дія & & & \\
\hline & & $(n=7)$ & II $(n=15)$ & III $(n=7)$ & & IV $(n=6)$ & \\
\hline Лейкоцити, Г/л & & $41 \pm 1,34$ & $5,14 \pm 0,93$ & $6,62 \pm 1,91$ & & $4,12 \pm 2,40$ & $6,73 \pm 0,62$ \\
\hline Лімфоцити, Г/л & & $08 \pm 0,80$ & $1,44 \pm 0,42$ & $0,83 \pm 0,48^{*, * *}$ & & $0,47 \pm 0,31^{*, * *}$ & $2,68 \pm 0,45$ \\
\hline CD3, клітин/мкл & 182 & $2,6 \pm 681,7$ & $1388,0 \pm 192,3^{*}$ & $1078,6 \pm 343,1^{*}$ & & $005,5 \pm 468,2^{*}$ & $1993,6 \pm 188,9$ \\
\hline CD4, клітин/мкЛ & 101 & $, 2 \pm 233,3$ & $419,3 \pm 54,1^{*}$, ** & $317,7 \pm 52,6^{*}$, ** & & $17,9 \pm 82,4^{*},{ }^{* *}$ & $1422,5 \pm 95,7$ \\
\hline CD8, клітин/мкЛ & & $6,6 \pm 89,9$ & $730,3 \pm 52,4^{*}$, ** & $829,0 \pm 85,6^{*}$, ** & & $590,3 \pm 110,5$ & $537,8 \pm 60,2$ \\
\hline CD16, клітин/мкл & & $1,7 \pm 82,6$ & $292,6 \pm 30,7$ & $288,9 \pm 54,4$ & & $243,8 \pm 49,3$ & $354,3 \pm 51,0$ \\
\hline CD4/CD8 & & $71 \pm 0,26^{*}$ & $0,57 \pm 0,15^{*}$, ** & $0,38 \pm 0,20^{*},{ }^{* *}$ & & $0,20 \pm 0,11^{*, * *}$ & $2,65 \pm 0,27$ \\
\hline ІЛ-8, пг/мЛ & & $37 \pm 14,23^{*}$ & $76,02 \pm 19,21^{*}$ & $96,15 \pm 36,07^{*}$ & & $2,16 \pm 49,11^{*}$, ** & $14,38 \pm 5,66$ \\
\hline ІЛ-10, пг/мл & 1,2 & $63 \pm 0,547^{*}$ & $2,363 \pm 0,408^{*, * *}$ & $3,965 \pm 0,934^{*}$, ** & & $408 \pm 1,418^{*}$, ,* & $0,118 \pm 0,033$ \\
\hline ІЛ-12, пг/мЛ & & $45 \pm 2,44$ & $5,89 \pm 1,23$ & $3,84 \pm 1,96$ & & $1,53 \pm 0,88^{*, * \star}$ & $7,85 \pm 2,13$ \\
\hline ІЛ-17, пг/мЛ & & $25 \pm 0,364$ & $1,348 \pm 0,516$ & $0,820 \pm 0,315$ & & $927 \pm 0,520^{*}$, ,* & $0,534 \pm 0,141$ \\
\hline $\lg \mathrm{A}$, г/л & & $64 \pm 0,61$ & $2,32 \pm 0,34^{*}$ & $2,64 \pm 0,47^{*}$ & & $1,81 \pm 0,51$ & $1,39 \pm 0,26$ \\
\hline $\operatorname{lgM}$, г/л & & $73 \pm 0,52$ & $1,28 \pm 0,33$ & $1,10 \pm 0,46$ & & $0,85 \pm 0,44$ & $1,88 \pm 0,31$ \\
\hline $\operatorname{lgG}$, г/л & & $24 \pm 1,76$ & $5,79 \pm 0,85$ & $6,41 \pm 1,59$ & & $5,43 \pm 1,46$ & $6,54 \pm 1,60$ \\
\hline ЦІК, опт. од. & & $6 \pm 12,7$ & $118,9 \pm 25,3^{*}, * *$ & $152,4 \pm 51,0^{*},{ }^{* *}$ & & $91,2 \pm 68,6^{*}$, ,* & $52,7 \pm 8,5$ \\
\hline
\end{tabular}

Примітки: * - достовірна різниця порівняно з показником у здорових осіб за критерієм Манна-Уїтні $(p<0,05-0,02)$,

** - достовірна різниця порівняно з відповідним показником у хворих на герпесвірусну інфекцію $(p<0,05-0,02)$.

При поєднаному перебігу ВІЛ- і герпетичної інфрекції, коли в організмі присутні два конкуруючі віруси, вміст лейкоцитів, CD3- і CD16-клітин достовірно не відрізняється від показників при герпетичній моноінорекції ( $p>0,05)$.

IPI значно знижується при поєднаному перебігу герпесвірусної інфекції на тлі ВІЛ-інфрікування $(0,65 \pm 0,32)$ при II, $(0,46 \pm 0,22)$ при III і $(0,26 \pm 0,13)$ при IV клінічній стадії імунодесріциту відповідно проти $(2,12 \pm 0,28)$ при герпетичній інфекції $(p<0,05-0,02) .3 а$ наявності вірусу герпесу в організмі ВІЛ-інфрікованих дещо меншою мірою знижується імунорегуляторний показник, що свідчить про певний конкуруючий вплив вірусу герпесу на регуляторні субпопуляції (мал. 2).

При поєднанні ВІЛ- та герпесвірусної інфекції рівні цитокінів зазнавали ще значніших змін (табл. 1). Так, показники ІЛ-8 та ІЛ-10 статистично суттєво зростали не тільки з прогресуванням імунодефріциту, але й незалежно від клінічної стадії недуги, вагомо перевищуючи значення відповідного показника у хворих на герпетичну інфекцію. Зокрема рівень ІЛ-8 коливався в діапазоні $(65,34 \pm 17,08)$ $(227,06 \pm 53,97)$ пг/мл, а ІЛ-10 - від $(2,248 \pm 0,576)$ пг/мл при I клінічній стадії ВІЛ-інфекції до $(6,493 \pm 1,210)$ пг/ мл при термінальній стадії імунодесріциту. У хворих на 
ОРИГІНАЛЬНІ ДОСЛІДЖЕННЯ

герпесвірусну інфекцію середнє значення ІЛ-8 становило $(22,23 \pm 7,53)$, а ІЛ-10 - $(0,185 \pm 0,074)$ пг/мл (в усіх випадках $\mathrm{p}<0,05-0,02)$.

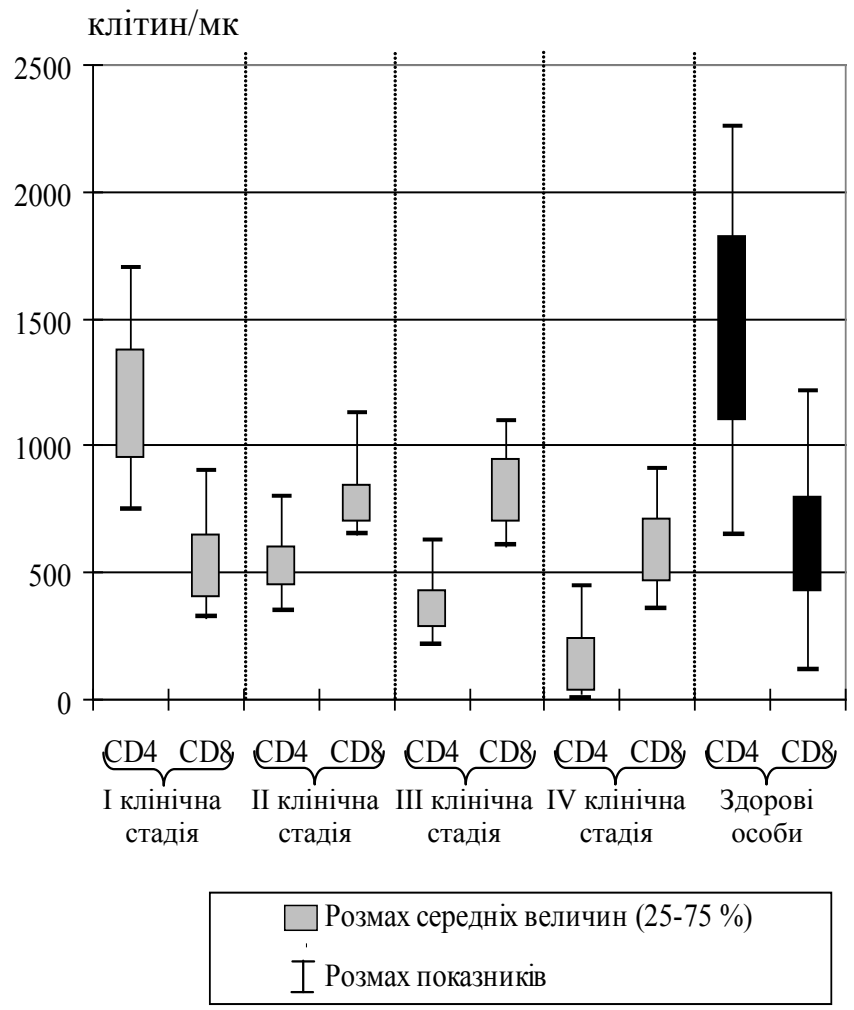

Мал. 1. Показники CD4- і CD8-клітин у хворих на поєднану ВIЛ- і герпетичну інфекцію.

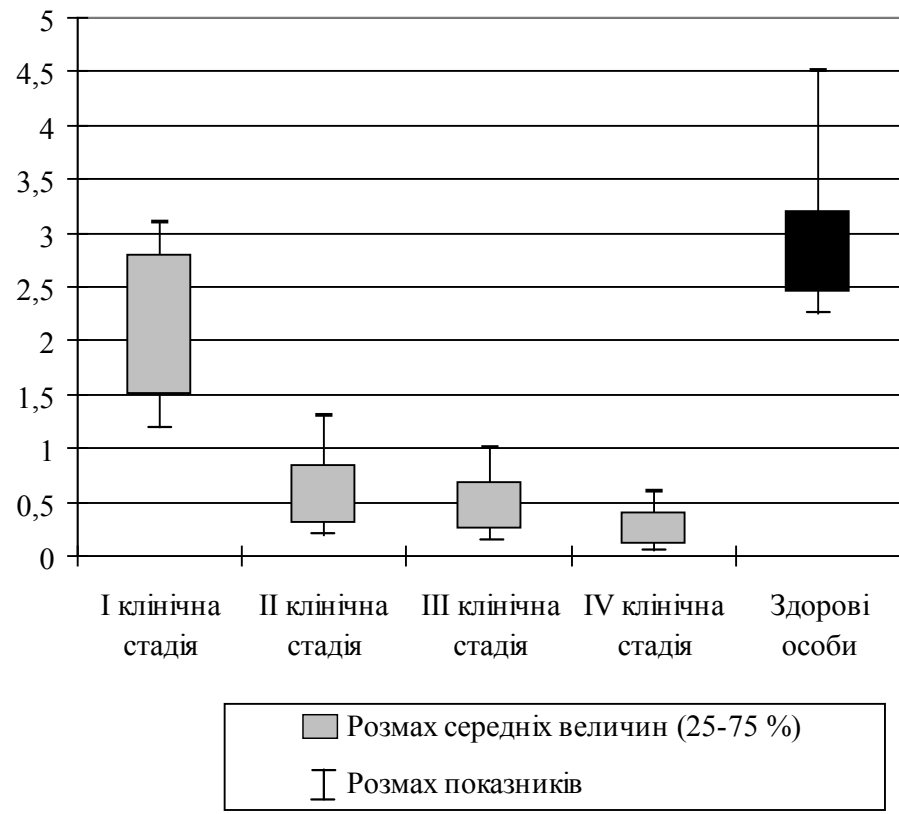

Мал. 2. Показники IPI у хворих на поєднану ВІЛ- і герпетичну інфекцію. 


\section{ОРИГІНАЛЬНІ ДОСЛІДЖЕННЯ}

Подібно до хворих на ВІЛ-моноінфекцію значення ІЛ-17 характеризувалося тенденцією до зростання і тільки при термінальній стадії комбінованої недуги воно досягало $(2,850 \pm 0,761)$ пг/мл, що статистично вагомо перевищувало не тільки нормальний рівень, але й відповідний показник при герпетичній іноекції $(0,652 \pm 0,237)$ пг/мл $(p<0,05)$

Натомість при комбінації ВІЛ- і герпетичної інфрекції концентрація ІЛ-12 знижувалася, причому найзначнішого зниження зазнавала лише у термінальній стадії імунодесіциту - $(1,22 \pm 0,70)$ пг/мл, що не тільки достовірно відрізнялося від показника у здорових осіб $(p<0,05)$, але й у хворих на герпесвірусну інфекцію - $(5,48 \pm 1,61)$ пг/ мл (р<0,05, табл. 1).

Порівняно з хворими на ВІЛ-моноінсекцію показники сироваткових рівнів ІЛ-8, ІЛ-10 та ІЛ-17 не зазнавали достовірних змін, хоча можна констатувати тенденцію до деякого зростання їх значень. Такою ж тенденцією до зниження характеризується і рівень ІЛ-12.

При аналізі показників клітинної ланки імунітету і вмісту цитокінів у сироватці крові хворих з поєднанням ВІЛ- і герпетичної інфекції виявили сильну зворотну кореляцію $(r=-0,72, p<0,05)$ між рівнем ІЛ-8 і кількістю CD4-лімфоцитів, сильну зворотну кореляцію ( $r=-0,79$, p<0,05) між значенням IЛ-10 і кількістю CD4-лімфоцитів, зворотну кореляцію середньої сили $(r=-0,35, p<0,05)$ між вмістом ІЛ-17 і кількістю CD4-лімфоцитів, а також слабку пряму $(r=0,08, p<0,05)$ - між значеннями IЛ-12 та кількістю CD4-лімфроцитів.

Таким чином, у хворих на ВІЛ- і герпетичну коінсрекцію співвідношення сироваткових концентрацій ІЛ-8, ІЛ-10, ІЛ-12 та ІЛ-17 зазнає максимального дисбалансу. Причому значно зростає вміст не тільки прозапальних (ІЛ-8, ІЛ-17), але й протизапального цитокіну ІЛ-10. Водночас значно знижується рівень прозапального ІЛ-12 у хворих з тяжким ступенем імуносупресії. Паралельно суттєво зростає сироватковий рівень протизапального цитокіну ІЛ-10 на всіх стадіях комбінованої ВІЛ- та герпесвірусної інфекції, незалежно від клінічної стадії недуги.

Отже, показники клітинного імунітету в порівнюваних групах значно змінюються і вони можуть бути одними 3 критеріїв оцінки активності патологічного процесу і прогнозу захворювання.

Показники гуморального імунітету змінювалися значно меншою мірою, ніж рівні клітинного імунітету. Так, на відміну від хворих на ВІЛ-моноінфекцію, титр IgA не зазнавав достовірних змін порівняно зі здоровими особами, хоча можна відзначити тенденцію до підвищення його рівня передусім при II і III клінічних стадіях ВІЛінсекції - $(2,32 \pm 0,34)$ і $(2,64 \pm 0,47)$ г/л відповідно проти $(1,39 \pm 0,26)$ г/л у нормі (в усіх групах хворих р>0,05). Відомо, що $\lg A €$ секреторним імуноглобуліном і певною мірою забезпечує місцевий імунітет на рівні слизових оболонок. Підвищення його титру забезпечує захист організму від інфекції на місцевому, тканинному або органному рівні. Дані наших досліджень з вивчення IgA при герпетичній інфекції збігаються з результатами інших авторів [8]. Проте ми виявили, що при поєднаному перебігу герпетичної інсекції на тлі ВІЛ-інорікування вміст $\lg$ А практично не змінюється. Очевидно, наявність двох вірулентних вірусів в цілому пригнічує імунну відповідь, тому рівень IgA може бути меншим, ніж за наявності в організмі одного із зазначених вірусів. Вміст IgM та IgG також достовірно не відрізнявся від показників у здорових осіб ( $>>0,05)$, що не суперечить даним літератури [8].

А от вміст циркулюючих імунних комплексів достовірно зростає в групі ВІЛ-позитивних осіб, коінорікованих герпесвірусами, при II, III і IV клінічних стадіях ВІЛінсрекції - $(144,9 \pm 24,3),(168,0 \pm 55,2)$ і $(199,6 \pm 64,0)$ опт. од. відповідно проти $(52,7 \pm 8,5)$ опт. од. у здорових осіб $(\mathrm{p}<0,05)$ (мал. 3).

Вважаємо, що при одночасній присутності в організмі двох вірусів сповільнюється елімінація ЦІК з організму, оскільки у звільненні організму від імунних комплексів беруть участь майже всі імуноцити у взаємодії з цитокіновою системою. Нашими дослідженнями (табл. 1) встановлено зниження показників клітинного імунітету передусім у групі хворих на герпетичну інфекцію на тлі ВІЛ/інфекції, що призводить до ослаблення імунної відповіді і накопичення імунних комплексів в організмі.

Таким чином, встановили зниження основних показників клітинного імунітету, особливо CD4 та CD8 фенотипу лімфоцитів при ВІЛ-моноінфекції. Та баланс вмісту CD4- і CD8-клітин особливо порушувався у хворих на ГВІ на тлі ВІЛ-інфікування. Причому у більшої частини хворих кількість CD8-клітин була вища за вміст CD4клітин. При порівнянні з показниками цих клітин у здорових осіб виявили, що дисбаланс пов'язаний з різким зниженням кількості CD4-клітин. При такій комбінації відзначили також максимальний дисбаланс сироваткових концентрацій ІЛ-8, ІЛ-10, ІЛ-12 та ІЛ-17. Причому значно зростав вміст не тільки прозапальних (ІЛ-8, ІЛ-17), але й протизапального цитокіну ІЛ-10. Водночас значно знижувався рівень прозапального ІЛ-12 у хворих з тяжким ступенем імуносупресії. Паралельно суттєво зростав сироватковий рівень протизапального цитокіну ІЛ-10 на всіх стадіях комбінованої ВІЛ- та герпесвірусної інфекції, незалежно від клінічної стадії недуги. У хворих з таким поєднанням вірусних інфрекцій ще й суттєво зростав рівень циркулюючих імунних комплексів при практично незмінному титрі імуноглобулінів A, M i G. Виявлені зміни в імунному статусі різного ступеня у хворих в спостережуваних групах можуть служити критерієм оцінки тяжкості перебігу і прогнозу захворювань. 


\section{ОРИГІНАЛЬНІ ДОСЛІДЖЕННЯ}

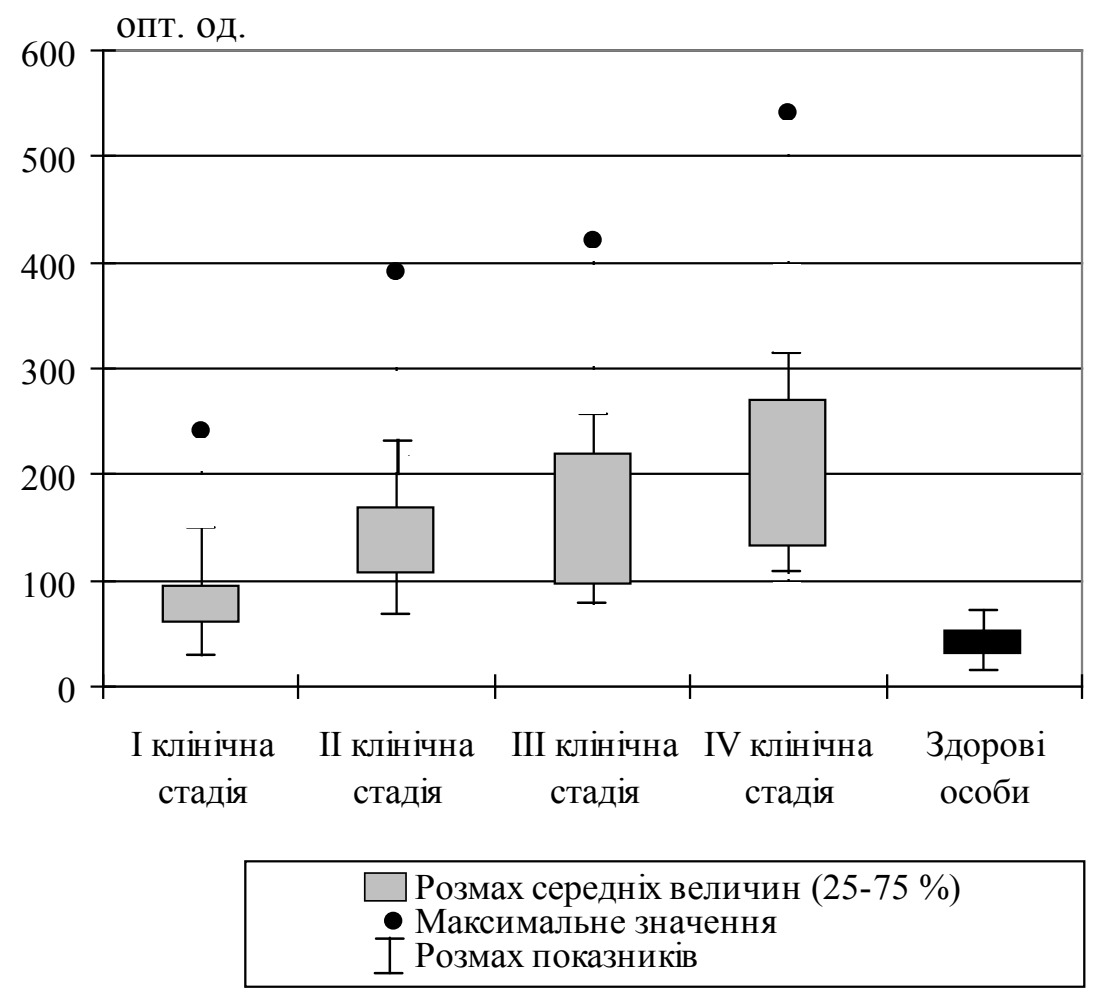

Мал. 3. Циркулюючі імунні комплекси у хворих на поєднану ВІЛ- і герпетичну інфекцію.

Проаналізувавши рівень ЦІК у ВІЛ-позитивних хворих на фоні герпесвірусних інфекцій з використанням програми StatSoft Statistica 6.0, встановили, що саме у цій групі пацієнтів цей показник найвищий, причому, максимальне значення концентрації ЦІК становило аж 540 опт. од.

Вказаний математичний метод підтвердив, що найбільш значуще збільшення вмісту ЦІК відзначено у хворих на герпесвірусні інфекції на тлі набутого імунодефіциту. Як було зазначено, два високопатогенних віруси впливають на всі ланки імунної відповіді, імунні комплекси, що беруть участь в елімінації, від макрофрагально-фрагоцитарної системи до антитілозалежної цитотоксичності, у тому числі і на поліклональну активність синтезу антитіл.

\section{Висновки}

1. У хворих на ВІЛ-інфрекцію у поєднанні з герпетичною інфекцією (лабіальний герпес та/або афтозний стоматит, генітальний, оперізувальний герпес та інфрекційний мононуклеоз, окремо чи в комбінації) вміст лімфоциитів при III і IV клінічній стадії імунодефріциту був нижчим, ніж при герпетичній моноінфекції. Таким же було зниження рівня CD4 при II-IV стадії ВIЛ-інсрекції у комбінації з герпетичною інфекцією і відносне збільшення кількості Т-супресорів порівняно 3 герпетичною моноінфрекцією. За наявності вірусу герпесу в організмі ВІЛ-інорікованих дещо менше знижувався імунорегуляторний показник, що свідчить про певний конкуруючий вплив вірусу герпесу на регуляторні субпопуляції.

2. У хворих на ВІЛ- і герпетичну коінфекцію співвідношення сироваткових концентрацій ІЛ-8, ІЛ-10, ІЛ-12 та ІЛ-17 зазнавало максимального дисбалансу. Причому значно зростав вміст не тільки прозапальних (ІЛ-8, ІЛ-17), але й протизапального цитокіну ІЛ-10. Водночас значно знижувався рівень прозапального ІЛ-12 у хворих 3 тяжким ступенем імуносупресії. Паралельно суттєво зростав сироватковий рівень протизапального цитокіну ІЛ-10 на всіх стадіях комбінованої ВІЛ- та герпесвірусної інфрекції, незалежно від клінічної стадії недуги.

3. При поєднанні ВІЛ- і герпетичної інфрекції виявили сильну зворотну кореляцію між рівнем ІЛ-8 і кількістю CD4-лімфроцитів, сильну зворотну кореляцію між значенням ІЛ-10 і кількістю CD4-лімфоцитів, зворотну кореляцію середньої сили між вмістом ІЛ-17 і кількістю CD4-лімфоццитів, а також слабку пряму - між значеннями ІЛ-12 та кількістю CD4-лімфроцитів.

4. У хворих з таким поєднанням вірусних інфекцій ще й суттєво зростав рівень циркулюючих імунних комплексів при практично незмінних титрах імуноглобулінів A, M i G. 


\section{ОРИГІНАЛЬНІ ДОСЛІДЖЕННЯ}

\section{Література}

1. Магнітнорезонансна та комп'ютерна томограсрія головного мозку при герпесвірусних енцефалітах / В.В. Кононенко, О.П. Робак, В.О. Рогожин, О.Я. Главацький // Інфекційні хвороби. - 2004. - № 3. - С. 9-15.

2. Короленко В.В. Питання діагностики та лікування генітального герпесу на сучасному етапі / В.В. Короленко // Укр. журн. дерматол., венерол., косметол. - 2010. - № 1. - С. 85-91.

3. Лабораторна діагностика герпесвірусної інфекції людини / [Л.О. Панченко, І.І. Торяник, Н.Г. Попова та ін.] // Інфекційні хвороби. - 2006. - № 3. - С. 62-66.

4. Лікування герпесвірусних інфекцій в сучасних умовах / О.Г. Андреєва, А.О. Руденко, Т.Г. Берестова, Н.С. Руденко // Профрілактична медицина. - 2011. - № 3. - С. 68-72.

5. Barton S.E. Herpes management and prophylaxis / S.E. Barton // Dermatol. Clin. - 2008. - Vol. 16. - P. 799-803.

6. Лапач С.Н. Статистические методы в медико-биологических исследованиях с использованием Excell / С.Н. Лапач, А.В. Чубенко, П.Н. Бабич. - Киев: МОРИОН, 2000. - 320 с.

7. Хаитов Р.М. Экологическая иммунология / Р.М. Хаитов, Б.В. Пинегин, Х.И. Истамов. - М : Изд-во ВНИРО, 2005. - 219 с.

8. Исаков В.А. Противовирусная терапия герпеса у больных с иммунодесрицитами / В.А. Исаков, М.М. Сафронова, Ю.В. Аспель // Terra Medica. - 2009. - № 2. - C. 12-14.

\section{IMMUNE STATUS OF PATIENTS WITH HSV INFECTION ON THE BACKGROUND OF HIV/AIDS}

V.D. Moskaliuk, M.O. Sokolenko, V.D. Sorokhan

SUMMARY. An examination of 37 patients with HIV infection in combination with herpetic infection (herpes labial and / or thrush, genital, herpes zoster and infectious mononucleosis alone or in combination) showed that in the case of this combination lymphocyte content in III and IV clinical stage was immunodeficiency significantly lower than the herpetic monoinfection. Similarly significant was the reduction in CD4 II-IV stage of HIV infection in combination with herpetic infection and relative increase in the number of T-suppressor compared with herpetic monoinfection. In the presence of herpes virus in the body of HIV-infected to a lesser extent, reduced immunoregulatory index, which indicates the influence of a competing herpes virus regulatory subpopulation.

In patients with HIV and herpes co-infection ratio of serum concentrations of IL-8, IL-10, IL-12 and IL-17 undergoes maximum imbalance. And significantly increases content is not only pro-inflammatory (IL-8, IL-17), but also anti-inflammatory cytokine $\mathrm{IL}-10$. At the same time significantly reduced levels of proinflammatory IL-12 in patients with severe immunosuppression. In parallel, significantly increasing serum anti-inflammatory cytokine IL-10 at all stages of combined HIV and herpes infection, regardless of clinical stage disease.

When combined HIV and herpes infections found a strong inverse correlation between IL-8 and the number of CD4-lymphocytes ( $r=-0,72, p<0.05)$, a strong inverse correlation $(r=-0,79, p<0,05)$ between the value of IL-10 and the number of CD4-lymphocytes inverse correlation of medium strength $(r=-0,35, p<0,05)$ between the content of IL-17 and the number of CD4-lymphocytes, and weak direct $(r=0,08, p<0,05)$ - between the values of IL-12 and the number of CD4-lymphocytes.

In patients with the combination of viral infections also significantly increases the level of circulating immune complexes with almost constant titre immunoglobulin $A, M$ and $G$.

Key words: HIV, herpes infection, cellular and humoral immunity, cytokine status.

Отримано 20.03.2015 р. 